\title{
Perilaku Cyberbullying Mahasiswa dengan Teman Sebaya
}

\author{
${ }^{1}$ Siti Khanifah Putri Kurnia Pratiwi, ${ }^{2}$ Rina Sari Kusuma \\ Fakultas Komunikasi dan Informatika, Universitas Muhammadiyah Surakarta, Jl. Ahmad Yani, Pabelan, \\ Kartasura, Surakarta 57162, Jawa Tengah \\ E-mail: 1's.khanifah.putri@outlook.co.id, 2rinasari.kusuma@ums.ac.id
}

\begin{abstract}
Abstrak: Perkembangan teknologi komunikasi dan informasi mengubah pola komunikasi online masyarakat secara bertahap, hingga memunculkan perilaku toxic disinhibition online effect dimana kurangnya pengendalian diri sehingga cenderung bersikap agresif ketika berkomunikasi secara online daripada berkomunikasi secara langsung. Perilaku agresif tersebut kemudian ditunjukkan dalam tindakan cyberbullying. Cyberbullying merupakan perilaku agresif, intens, dan berulang yang dilakukan dengan menggunakan teknologi dan elektronik sebagai media untuk menyerang seseorang. Tujuan penelitian ini adalah mengetahui bagaimana konsep diri pelaku cyberbullying dan juga bentuk - bentuk tindakan cyberbullying yang dilakukannya. Penelitian ini merupakan penelitian kualitatif yang ditujukan untuk memahami fenomena cyberbullying di kalangan mahasiswa UMS. Sifat penelitian ini adalah deskriptifyang bertujuan memberikan gambaran secara obyektif tentang keadaan sebenarnya dari objek yang diteliti. Peneliti menggunakan snowball sampling dalam menentukan subjek penelitian yang dianggap dapat memberikan informasi untuk kepentingan penelitian yang dilakukan dan didapatkan tiga orang. Teknik pengumpulan data yang digunakan adalah dengan teknik wawancara mendalam (depth interviews). Dalam penelitian ini terlihat bahwa perilaku cyberbullying terdapat pada mahasiswa yang memiliki konsep diri positif dan negatif. Tindakan cyberbullying yang dilakukan adalah, flamming, harassment, denigration, cyber-stalking, impersonation, outing, dan exclusion. Tindakan-tindakan cyberbullying tersebut mereka lakukan dengan perantara media online, baik melalui messanger ataupun melalui social media.
\end{abstract}

Kata kunci: pelaku, cyberbullying, konsep diri, media online.

Abstract: The development of communication and information technology changes the community's online communication pattern gradually, to elicit the toxic behavior disinhibition online effect where lack of self-control or even tends to be aggressive when Communicate online rather than communicating directly. These aggressive behaviors are then demonstrated in cyberbullying action. Cyberbullying is an aggressive, intense, and repetitive behaviour that is performed using forms of technology and electronics as a medium to attack a person. This research purposes are to acknowledge the self concept of cyberbullying suspect and their forms of cyberbullying. This research is a qualitative research aiming to understand the phenomenon of cyberbullying among UMS students. The trait of this research is descriptive as its suppose to serve comprehensive objective description over the tangible situation of the observed object. The researcher uses the snowball sampling in order to define the observation subject which considered may provide proper information for this research and obtained by three people. The data collecting technique is depth interviews. In this research it shows the action of cyberbullying suspect is possessed by student with both positive and negative self concept. Some forms of cyberbullying are flamming, harassment, denigration, cyber-stalking, impersonation, outing, and exclusion. These actions of cyberbullying done by use of social media, both messenger and public social media.

Keyword: bullies, cyberbullying, self-concept, online media.

DOI: https://doi.org/10.29313/mediator.v12i2.4793 


\section{PENDAHULUAN}

Dalam perkembangan teknologi komunikasi daninformasi, telahdiciptakan situs, aplikasi, dan media sosial dengan harapan dapat membuat komunikasi antar manusia semakin baik dan praktis. Internet merupakan teknologi yang dapat merealisasikan harapan tersebut. Bahkan internet sekarang ini dapat dinikmati oleh semua lapisan masyarakat. Sayangnya, banyak pengguna internet yang menggunakan teknologi tersebut dengan tidak bertanggung jawab, sehingga menyebabkan banyaknya keluhan yang muncul akibat perilaku pengguna internet terutama di media sosial.

Menurut laporan survei oleh Asosiasi Penyelenggara Jasa Internet Indonesia (APJII) mengenai penetrasi dan perilaku pengguna internet Indonesia, pada tahun 2017 menunjukkan bahwa pengguna teknologi internet di Indonesia adalah 54,68\% atau sebanyak 143,26 juta dari 262 juta masyarakat Indonesia. Jumlah ini telah menunjukkan peningkatan dibandingkan tahun lalu pada laporan survei yang sama, yaitu 132,7 juta dari total populasi masyarakat Indonesia. Layanan yang paling banyak diakses adalah layanan chatting sebesar $89,35 \%$ yang kemudian disusul layanan media sosial sebesar 87,13\%. Dari sekian banyak pengguna internet, usia remaja hingga dewasa adalah penyumbang terbesar nya. Hal ini ditunjukkan dengan persentase pada usia 13 - 18 tahun sebesar $16,68 \%$ dan usia 19 - 34 tahun sebesar 49,5\%. Jumlah ini telah mengalami peningkatan dibandingkan tahun lalu yaitu untuk usia 10 - 24 tahun sebesar $18,4 \%$ dan usia 25 - 34 tahun sebesar 24,4\% (APJI, 2017).

Berbagai penelitian mengungkapkan bahwa terdapat perbedaan perilaku seseorang ketika online dibandingkan ketika offline. Hal ini yang kemudian dinamakan disinhibition online effect. Contohnya adalah ketika terdapat orang yang aktif di chatroom, akan tetapi pendiam ketika sedang bersama teman - teman kelasnya. Siegel, Dubrovsky, Kiesler dan McGuire juga berpendapat bahwa media online mampu mengurangi perbedaan status yang dapat diamati, sehingga memungkinkan orang untuk merasa lebih nyaman dan bebas dalam berbicara (Vranjes, Baillien, Vandebosch, Erreygers, \& De Witte, 2017). Sayangnya, perilaku tersebut ada yang mengarah kepada perilaku negatif, yaitu toxic disinhibition online effect karena kurangnya pengendalian diri atau bahkan cenderung bersikap agresif ketika berkomunikasi secara online daripada berkomunikasi secara langsung (Satriawan, 2014).

Berthold dan Hoover (2000) mengatakan bahwa perilaku agresi merupakan manifestasi dari gaya hidup orangtua dan terus berlanjut kepada anak dari masa remaja dan dewasa. Olweus dan Alsaker juga mengemukakan bahwa penindasan merupakan perilaku antisosial oleh pelajar dan dapat menimbulkan risiko di lingkungan sekolah (Berthold \& Hoover, 2000).

Menurut Hertz, cyberbullying merupakan bentuk perundungan dan kekerasan dengan cara mengejek, mengatakan kata - kata kasar, mengatakan kebohongan, menyebarkan rumor atau melakukan ancaman atau berkomentar secara agresif yang dilakukan dengan perantara media cyber seperti email, chat room, pesan instan, website atau pesan singkat (SMS). Sedangkan menurut Hinduja \& Patchin, dan Smith, dkk cyberbullying adalah perilaku agresif oleh individu atau kelompok yang dilakukan secara insten atau berulang dengan memanfaatkan teknologi dan elektronik sebagai media untuk menyerang seseorang (Akbar, 2015).

Dalam penelitian Muhammad Nur Wangid (2017) disebutkan bahwa dari 497 mahasiswa yang menjadi responden nya, terdapat sebesar $36,25 \%$ mahasiswa yang 
mengaku telah melakukan cyberbullying. Persentase ini mengalami peningkatan tajam dari penelitian yang dilakukan Li hanya mencapai $17 \%$ dan MacDonald and Robert-Pittman yang hanya $8,6 \%$. Hal ini dapat menunjukkan bahwa ternyata pada kalangan mahasiswa masih banyak yang tidak mempertimbangkan dampak buruk dari cyberbullying dan penyalahgunaan internet (Wangid, 2017).

Sayangnya, kasus cyberbullying seringkali terjadi dalam hubungan pertemanan. Dalam penelitian Mutia Mawardah dan MG. Adiyanti (2014) ditunjukkan bahwa penelitian media online Ipsos, telah meneliti secara online di 24 negara dengan menggunakan responden 18.867 orang, menunjukkan Indonesia merupakan urutan pertama (53\%), dimana cyberbullying terjadi dalam komunitas pertemanan mereka (Mawardah \& Adiyanti, 2016).

Faktor yang memicu terjadinya kasus cyberbullying tersebut salah satunya adalah adanya konformitas dalam kelompok teman sebaya. Menurut Worchel \& Cooper, konformitas adalah penyesuaian atau perubahan persepsi, keyakinan dan perilaku seseorang karena adanya tekanan dan tuntutan dari kelompok pertemanan (De Vito, 2011).

Hal ini menjadi salah satu pemicu adanya konflik dan juga pertikaian didalam kelompok teman sebaya apabila persepsi yang dibangun tidak dapat sesuai. Apabila seseorang dalam suatu kelompok tidak dapat menyesuaikan tuntutan tersebut, maka orang tersebut akan tereliminasi dan bahkan akhirnya dapat menjadi sasaran bullying/cyberbullying.

Salah satu hal yang mempengaruhi interaksi seorang individu dengan kelompoknya adalah konsep diri. Williarn D. Brooks mengartikan konsep diri sebagai "those physical, social, and psychological perceptions of ourselves that we have derived from experiences and our interaction with others". Jadi, konsep diri merupakan perasaan dan pandangan kita tentang diri sendiri yang bersifat psikologi, sosial, dan fisik (Rakhmat, 2015). Terdapat 2 jenis konsep diri, yaitu konsep diri positif dan konsep diri negatif (Saifullah, 2016) : (a) Konsep diri positif. Konsep diri positif merupakan sikap penerimaan diri yang bersifat stabil dan variatif namun bukan kebanggaan yang besar tentang diri. Konsep diri positif ditunjukkan oleh seseorang dengan mengetahui betul tentang dirinya, mampu memahami dan menerima fakta lain tentang dirinya sendiri dan mampu menerima keberadaan orang lain; (b) Konsep diri negatif. Tipe konsep diri negatif terbagi menjadi 2, yaitu: (1) Pandangan dirinya sendiri yang benar-benar tidak teratur, tidak memiliki perasaan kestabilan dan keutuhan diri. Seseorang tersebut tidak mengetahui siapa dirinya, kekuatan dan kelemahannya serta apa dihargai dalam dirinya. (2) Pandangan dirinya sendiri yang justru terlalu stabil dan teratur. Hal ini dikarenakan seseorang dididik dengan cara yang terlalu keras, hingga terciptanya perilaku yang tidak baik.

Pembentukan konsep diri dipengaruhi oleh banyak faktor lain, termasuk peran orang-orang terdekat, masyarakat, dan lingkungannya, sehingga konsep diri memiliki hubungan yang erat dengan kelekatan. Hal ini dikarenakan konsep diri mulai terbentuk saat anak berada pada usia dini. Kelekatan (attachment) menurut John Bowlby merupakan kecenderungan serta keinginan seseorang dalam mencari kedekatan dan kepuasan dalam suatu hubungan dengan orang lain. Teori ini mencoba menjelaskan pola relasi orangtua dan anak yang ada sejak bayi (Cenceng, 2015). Bowbly meyebutkan terdapat tiga pola attachment (kelekatan), yaitu: (1) Secure attachment (pola kelekatan aman). Pola ini merupakan bentuk interaksi ketika anak merasa percaya terhadap 
orang tua sebagai pihak yang selalu siap mendampingi, peka, responsif, penuh cinta dan kasih sayang ketika anak mencari perlindungan dan kenyamanan. Orang tua juga selalu berusaha ada dan membantu anak apabila sedang menghadapi situasi yang mengancam, sulit, dan memerlukan bantuan. (2) Resistant attachment (pola kelekatan ambivalen). Pola ini menunjukkan saat anak merasa tidak pasti bahwa orang tuanya selalu ada dan cepat membantu ketika anak membutuhkan mereka. Akibatnya, dalam pertumbuhannya anak seringkali mengalami kecemasan berpisah, cenderung bergantung dengan orang lain, seringkali menuntut perhatian dan cemas dalam mengeksplorasi lingkungannya. Seseorang yang ambivalen akan kesulitan dalam berhubungan dengan orang lain karena respons yang tidak konsisten pada orangtuanya. (3) Avoidant attachment (pola kelekatan menghindar). Pola kelekatan yang terbentuk karena orang tua selalu menghindari anak dan mangakibatkan sang anak juga melakukan penolakan terhadap orang tuanya. Sehingga anak tidak memiliki kepercayaan diri karena dirinya tidak direspon atau bahkan ditolak oleh orang tuanya. Anak kemudian cenderung memenuhi kebutuhan kasih sayang nya sendiri dengan lingkungan luarnya. Anak yang memiliki pola kelekatan ini cenderung tidak nyaman dan berusaha menghindari orang tuanya (Cenceng, 2015).

Kasus - kasus cyberbullying yang terjadi kemudian menimbulkan pertanyaan mengenai apa yang menjadi latar belakang kasus cyberbullying dapat terjadi. Peneliti tertarik untuk melakukan penelitian dari segi pelaku terkait tindakan cyberbullying, baik itu pada mesenger atau pada platform media sosial tertentu. Dalam penelitian kualitatif deskriptif ini, peneliti akan memberikan penggambaran yang objektif dan mendalam mengenai pelaku cyberbullying. Tujuan penelitian ini adalah mengetahui bagaimana konsep diri pelaku cyberbullying dan juga bentuk-bentuk tindakan cyberbullying yang dilakukannya.

\section{METODE}

Penelitian ini merupakan penelitian kualitatif yang bertujuan untuk melakukan penafsiran terhadap realitas atau fenomena sosial. Penelitian kualitatif dilakukan untuk memberikan pemahaman atas fenomena sosial dari sudut pandang atau perspektif subjek (Pujileksono, 2015). Sifat penelitian ini adalah deskriptif yang bertujuan memberikan gambaran tentang keadaan sebenarnya dari objek yang diteliti secara obyektif (Amiruddin, 2016).

Peneliti menggunakan mahasiswa Universitas Muhammadiyah Surakarta sebagai populasi penelitian ini. Peneliti ingin melihat bagaimana fenomena cyberbullying ini terjadi di dalam lingkup pertemanan mahasiswa-mahasiswa tersebut. Peneliti menggunakan snowball sampling dalam menentukan subjek penelitian. Peneliti telah menyeleksi tiga orang untuk menjadi responden penelitian yang dianggap dapat memberikan informasi untuk kepentingan penelitian yang dilakukan (TABEL 1). Latar belakang mahasiswa menjadi titik berat dalam pemilihan subjek penelitian. Latar

TABEL 1. Profil Informan

\begin{tabular}{ccc}
\hline Responden (umur) & Gender & Program Studi \\
\hline A (22 tahun) & Laki-laki & Teknik Informatika \\
B (21 tahun) & Perempuan & Ilmu Komunikasi \\
C $(21$ tahun $)$ & Perempuan & Ilmu Komunikasi \\
\hline
\end{tabular}


belakang tersebut adalah mereka yang memiliki pengalaman menjadi pelaku cyberbullying. Peneliti menggunakan teknik wawancara mendalam (depth interviews) untuk mendapatkan data wawancara penelitian ini. Wawancara mendalam tersebut membuat peneliti mampu mendapatkan informasi secara langsung atas pertanyaan yang diajukan peneliti kepada responden. Dalam melakukan wawancara ini digunakan wawancara terbuka agar peneliti dapat menggali informasi selengkap dan sedalam mungkin sehingga terdapat kesesuaian pemahaman terhadap fenomena yang ada (Djaelani, 2014). Teknik ini tentunya cocok untuk menggali konsep diri subjek penelitian dalam melakukan cyberbullying.

Peneliti

menggunakan teknik analisis isi kualitatif dengan menggunakan rangkuman hasil penelitian dan interpretasi data dari pada hanya menggunakan kata-kata atau metode kualitatif lainnya. Teknik analisis isi bersifat sistematis dan transparan (Drisko \& Maschi, 2016), sedangkan teknik validitas data triangulasi sumber data digunakan peneliti untuk menggali kebenaran data atau informasi dengan berbagai sumber data yang berbeda (Pujileksono, 2015).

\section{TEMUAN DAN PEMBAHASAN Konsep Diri Pelaku Cyberbullying Konsep Diri Positif}

Berkaitan dengan hasil wawancara, ditemukan konsep diri positif yang dominan pada responden A dan responden C. Konsep diri positif yang ditemukan dalam wawancara, ditunjukkan dengan sikap percaya diri responden akan dirinya sendiri. Meskipun mengaku dinilai orang lain sebagai pribadi yang nakal, tetapi responden A tidak merasa rendah diri. Selain itu, responden A juga dapat menerima segala resiko yang responden dapatkan dari penilaian orang lain tersebut, misalnya terdapat beberapa orang yang tidak mau berteman dengannya dan responden juga mampu menjaga sikap ketika bertemu orang lain dengan kepribadian yang berbeda dengannya.

Karena ya itu risiko orang yang suka bully, kadang ada orang yang tidak suka sama becandaan saya dan tidak mau berteman dengan saya. Tapi saya seringnya merasa percaya diri sih, karena berarti teman-teman saya saat ini bisa nerima saya. (Responden A, 12 Maret 2019, UMS)

Sedangkan responden C meskipun sering mendapatkan olokan mengenai warna kulitnya yang hitam, responden mengaku tidak terlalu mempermasalahkannya dan dapat menerima diri nya sendiri apa adanya. Dalam pengakuannya, responden $\mathrm{C}$ juga mengatakan bahwa tidak memiliki acuan untuk menjadi seperti orang lain dan merasa percaya diri.

Ya udah karena ini aku gitu, karena kan ngga pernah punya acuan buat jadi orang lain atau apa yang bikin aku merasa ngga pede, aku sendiri itu kan ya aku apa adanya gitu, percaya sama diri aku sendiri gitu. (Responden C, 13 Maret 2019, UMS)

Konsep diri positif kedua responden tersebut sesuai dengan beberapa perilaku yang dikemukakan Jalaluddin (2015) sebagai perilaku seseorang dengan konsep diri positif, yaitu menyadari bahwa setiap orang mempunyai perbedaan perasaan, keinginan, dan perilaku yang mungkin saja tidak disetujui oleh masyarakat. Dalam hal ini ditunjukkan oleh kedua responden dengan sikap percaya diri. Selain itu, responden A juga dapat memperbaiki dirinya dengan mengungkapkan kepribadian dirinya yang tidak disenangi orang lain dan mau berusaha mengubahnya (Rakhmat, 2015).

Baumeister dan Boden menyatakan bahwa seseorang yang memiliki 
self esteem yang tinggi cenderung melakukan tindakan bullying. Hal ini dikarenakan self esteem tinggi dapat mendorong seseorang berperilaku agresi, sehingga memungkinkan untuk melakukan tindakan bullying (Makbul \& Agung, 2016). Dalam penelitian Persada terungkap beberapa motif yang mendorong seseorang untuk melakukan cyberbullying. Aneka motif tersebut untuk menyampaikan kekesalan terhadap korban, dengan harapan mengetahui kesalahannya, ingin menjatuhkan dan mempermalukan korban, merasa sakit hati hingga ingin membalas dendam, ingin mencari perhatian, dan untuk mencari kesenangan semata (Sartana, 2017).

\section{Konsep Diri Negatif}

Dalam penelitian ini, konsep diri negatif ditemukan pada responden $B$ yang berupa rendahnya kepercayaan diri responden.Haliniterjadikarenaresponden B pernah menjadi korban bullying oleh teman-teman sepermainannya.

Sebenarnya, saya susah untuk percaya diri. Misal ada orang yang menjatuhkan kepercayaan diri saya, saya itu lama sekali untuk bisa percaya diri lagi. Contohnya ketika saya dibully atau dijatuhkan harga diri saya di depan orang banyak. (Responden B, 13 Maret 2019, UMS)

Meskipun demikian, responden B memiliki kepribadian baik, yakni sifat yang memungkinan dirinya tidak sampai hati untuk menyakiti (tidak tega menyakiti) serta mudah memaafkan. Karena sifat ini lah responden mengaku seringkali disepelekan oleh temantemannya. Selain itu, konsep diri negatif juga mempengaruhi responden $\mathrm{B}$ dengan perasaan gagal apabila tidak melakukan apapun untuk orang lain (dengan ini, responden B merasa rendah diri dan kehilangan kepercayaan dirinya).

Konsep diri responden B tersebut termasuk dalam konsep diri negatif menurut William D. Brooks dan Philip Emmert (Rakhmat, 2015) yang ditandai dengan merasa tidak diperhatikan, tidak disenangi oleh orang lain, dan menganggap dirinya adalah korban dari kesalahan sistem sosial. Hal ini yang mendorong seseorang akhirnya memiliki self esteem rendah.

Dalam penelitian yang dilakukan Riauskina(Saifullah, 2016), menunjukkan bahwa konsep diri seseorang akan semakin negatif apabila dirinya pernah menjadi korban bullying. Kemudian dalam penelitian Sartana (2017), dijelaskan bahwa seringkali pelaku membully korban dengan alasan bercanda. Namun korban tidak berpikir demikian. Sehingga korban merasa malu dan tidak terima dengan tindakan tersebut. Perasaan itu menyebabkan korban membalas balik dengan mem-bully pelaku, sehingga cyberbullying berlangsung secara berulang (Sartana, 2017).

Hal ini diperkuat dengan penelitian Septrina (Malik, 2018) yang berbeda dengan penelitian Baumeister dan Boden, yaitu jika self esteem rendah maka semakin tinggi kecenderungan perilaku bullying. Rosenberg dan Kaplan (Setyaningrum, 2015) menjelaskan bahwa perasaan rendah diri yang dimiliki oleh seseorang dengan self esteem rendah dikompensasikan dalam perilaku negatif, yaitu bullying. Hal ini dilakukan dengan tujuan mencari perhatian dan pengakuan dari teman-temannya. Sejalan dengan penelitian tersebut, responden B mengompensasikan konsep diri negatifnya yang berupa ketidakpercayaan diri serta rasa rendah diri padanya dalam perilaku cyberbullying terhadap temantemannya agar mendapat pengakuan akan keberadaan diri responden, sehingga responden merasa berharga.

\section{Attachment (Kelekatan)}

Beberapa penelitian telah melihat hubungan antara bullying dan kualitas 
kelekatan anak dan remaja untuk kedua orang tua dan perilaku bullying mereka di antara teman-temannya. Smith dan Swettenham mengungkapkan bahwa pelaku cenderung memiliki pola kelekatan tidak aman atau pola menghindar, sementara sebagian besar korban tampaknya memiliki kelekatan yang aman (Kõiv, 2012).

Dalam penelitian ini, dari ketiga responden hanya ditemukan 2 pola kelekatan yang didapatkan antara responden dengan orang tua, yaitu sebagai berikut.

\section{Pola kelekatan ambivalen (resistant attachment)}

Menurut Ainsworth (dalam Williams, 2011), pola kelekatan ambivalen adalah suatu pola ketika anak tidak mendapatkan respon dan kepekaan orangtua akan kebutuhan anak secara konsisten, sehingga sang anak menjadi tidak yakin terhadap apa yang diharapkan oleh orangtua mereka.

Responden A dan responden B merasakan ketidakkonsistenan kasih sayang yang diberikan oleh orang tua. Responden A merasa perhatian dari orangtua yang ia dapatkan berubah setelah Ayah nya meninggal dunia. Responden juga mengaku bahwa tidak memiliki kecocokan pemikiran antara dirinya dengan ibunya, sehingga membuat responden mencari kenyamanan pada lingkungan lain di luar keluarganya. Sedangkan responden B mengaku bahwa dirinya merasa tertekan di dalam keluarga, hal ini dikarenakan responden B mengaku diberikan tanggung jawab untuk mengurus kedua adiknya dan seringkali ikut menanggung masalah keluarga. Responden B mengaku bahwa dirinya tak berani berkeluh kesah terlalu banyak kepada orangtua dikarenakan kesibukan atau adanya masalah yang sedang ditanggung oleh orangtuanya. Selain itu, responden $\mathrm{B}$ juga merasa bahwa orangtuanya seringkali tidak memahami posisinya di keluarga sebagai anak yang juga memiliki kesibukan di luar rumah.

Saya itu kan anak di keluarga, saya juga punya banyak masalah di teman, kuliah, tapi mereka seakan - akan tidak menganggap kesibukkan saya. Jadi fokusan mereka itu lebih ke adik. (Responden B, 13 Maret 2019, UMS)

Akan tetapi, di lain sisi responden B juga mengaku mendapatkan kasih sayang serta dipenuhi kebutuhannya oleh orang tua. Orangtua responden juga beberapa kali berusaha memberikan solusi apabila responden $\mathrm{B}$ memiliki masalah atau kesulitan, baik dalam hubungan pertemanan atau akademik.

Menurut Warren, Huston, Egeland, dan Sroufe (Williams, 2011), ketidakkonsistenan kelekatan antara orang tua dan anak memungkinkan sang anak tumbuh dalam kecemasan dan dapat menimbulkan kekacauan di kemudian hari. Penelitian Kristi Koiv (2012) juga menunjukkan bahwa pola kelekatan ambivalen tidak dapat membedakan antara pelaku dan korban bullying secara signifikan.

\section{Pola kelekatan aman (secure attachment)}

Ainsworth (Williams, 2011) mengatakan bahwa orangtua yang memiliki kelekatan aman cenderung jauh lebih sensitif terhadap kebutuhan anak mereka dibandingkan orangtua pada kelekatan tidak aman. Hal ini memungkinkan sang anak untuk percaya dan mengandalkan orangtua.

Berbeda dengan responden A dan $\mathrm{B}$, responden $\mathrm{C}$ cenderung masuk dalam pola kelekatan aman. Hal ini ditunjukkan dalam bentuk perhatian yang diberikan kepada responden. Meskipun jarak antara responden dan orang tua yang jauh, tetapi 
orang tua responden selalu menghubungi responden untuk menanyakan kabar. Orang tua responden juga berusaha memberikan solusi ketika responden sedang mendapatkan masalah.

Namun, responden $\mathrm{C}$ merasa tidak nyaman terhadap bentuk perhatian yang diberikan oleh orang tua nya. Hal ini dikarenakan responden merasa bahwa ia membutuhkan waktu untuk dirinya sendiri. Responden $\mathrm{C}$ mengaku bahwa orangtua nya terlalu mengekang dan tidak memberikannya ruang untuk bereksplorasi dalam dunia nya sendiri.

Over perhatian. Setiap hari komunikasi karna orang tuaku selalu pingin tau kabar aku terus. Tapi kadang aku sendiri yang mengabaikan mereka untuk ngasih kabar gitu, karena kan waktu aku juga terbagi-bagi kayak lagi pengen sendiri, ngumpul sama temen, atau pas lagi di kampus. Aku juga butuh waktu sendiri, ngga suka dikekang dan setiap saat harus ngabarin gitu.

(Responden C, 13 Maret 2019, UMS)

Dalam penelitian Watt (2014), hal ini menunjukkan adanya state of mind yang mengacu pada penafsiran responden terhadap pola kelekatan aman yang dialaminya. Representasi kelekatan yang ditafsirkan oleh responden $\mathrm{C}$ adalah pengekangan dari orangtua nya sehingga berdampak pada hubungan keduanya. Watt juga menjelaskan bahwa sikap orang tua yang mencoba mengendalikan perilaku anaknya melalui peraturan yang ketat dan menetapkan harapan yang tinggi mampu membuat sang anak merasa kurangnya empati dan responsif dari orang tua, meskipun niat mereka tidak selalu untuk menyakiti, menolak atau mengekang, sehingga, untuk mendapatkan rasa kontrol, pemahaman dan penerimaan, sang anak cenderung menunjukkan perilaku bullying (Watt,
2014).

\section{Perilaku Cyberbullying \\ Korban Cyberbullying \\ Teman Sebaya}

Bullying dalam pertemanan sebaya menjadi suatu kasus yang sering kali terjadi. Dalam portal berita $\mathrm{CNN}$ dijelaskan bahwa bullying di antara teman, juga dikenal sebagai relasional bullying, berasal dari kecenderungan alami untuk mengembangkan identitas berdasarkan teman. Anak-anak sering kali bergabung dengan kelompok yang ditentukan oleh siapa yang termasuk atau dikecualikan bahkan hingga melewati batas untuk menyakiti seseorang yang saat ini tidak masuk dalam kelompok mereka. Dalam penelitian Wei (2014) juga menunjukkan bahwa sebagian besar kasus, dalam proporsi yang signifikan (25 hingga 30\%) peristiwa bullying terjadi dalam konteks pertemanan sebaya.

Berdasarkan wawancara yang telah dilakukan, ketiga responden mengaku seringkali melakukan tindakan cyberbullying kepada teman sepermainan atau teman dekat responden.

\section{Kalau aku sih melakukannya ke teman dekat aja. Model ku itu yang penting dia terbully, orang - orang lain tertawa, trus ya udah. \\ (Responden A, 12 Maret 2019, UMS)}

Hal ini menunjukkan, bahwa karakteristik dari teman dan kualitas persahabatan menjadi hal yang penting. Bergaul dengan teman yang agresif dapat meningkatkan risiko terlibat dalam relasional bullying, terutama ketika ada ketidakseimbangan kekuasaan antar teman (Wei, 2011).

\section{Orang Asing}

Meskipun demikian, dalam tindakan cyberbullying, pihak yang menjadi korban bisa saja merupakan orang asing bagi pelaku. Kasus cyberbullying 
pada orang asing yang seringkali terlihat adalah kasus cyberbullying yang terjadi pada selebriti atau public figure. Seringkali kita melihat berbagai hujatan yang dilontarkan para haters atau antifans kepada selebriti tersebut melalui kolom komentar media sosial. Bahkan sekarang ini kita dapat menemukan beberapa akun yang khusus dibuat untuk mengungkapkan aib atau menyebarkan gosip para selebriti. Bahkan akun media sosial tersebut memiliki banyak pengikut yang juga seringkali mengomentari postingan tentang suatu gosip atau skandal selebriti dengan hujatan. Beberapa akun media sosial tersebut adalah lambe turah (6,6 juta pengikut), lambenyinyir (1,9 juta pengikut), makrumpita (880 ribu pengikut), dan masih banyak akun lainnya. Dengan anonimitas dalam media sosial, tentu tindakan-tindakan tersebut sangatlah mudah dilakukan oleh setiap orang.

Dalam penelitian ini pun, responden juga mengaku melakukan tindakan cyberbullying kepada orang asing. Misalnya responden A yang melakukan cyber-stalking terhadap orang asing yang telah menjelek-jelekkan atau mengolokoloknya di media sosial, dan juga tindakan impersonation yang dilakukan oleh responden $\mathrm{C}$ dengan menggunakan identitas saudara sepupunya untuk berkenalan dengan orang asing di media sosial. Selain itu, responden $C$ juga mengaku melakukan flamming kepada seseorang yang tidak dikenalnya saat di media sosial.

Misalnya kan lewat di timeline aku, dia kayak bikin komentar tentang orang lain. Nah, dia tuh kayak ngga ngeliat dia itu gimana dan malah ngatain orang lain. Ya kan aku yang liat jadi kesal gitu kan, jadi ikut kepancing buat ngatain dia.

(Responden C, 13 Maret 2019, UMS)

\section{Media Online Perantara dan Bentuk Tindakan \\ Messenger}

Dalam penelitian ini, aplikasi messenger masih mejadi tempat yang seringkali digunakan dalam tindakan cyberbulling. Beberapa tindakan cyberbullying bahkan dilakukan pada grup online. Hal ini tentu saja membuat korban dipermalukan di antara beberapa teman lain yang berada di dalam grup tersebut. Tindakan yang seringkali dilakukan, antara lain:

\section{(a) Flamming}

Cyberbullying yang berupa penggunaan bahasa yang mengandung amarah, ancaman, vulgar, dan merendahkan (Rastati, 2016). Dalam penelitian ini, ketiga responden menggunakan bahasa kasar dalam percakapan dengan teman mereka. Bahkan responden juga menggunakan bahasa vulgar atau cabul untuk mengolokolok teman.

Ya misalnya memanggil teman dengan sebutan "cuk" gitu.

(Kata "cuk" merupakan singkatan dari kata "Jancuk" yang berarti umpatan dari daerah Surabaya).

(Responden B, 12 Maret 2019, UMS)

\section{(b) Harassment}

Cyberbullying yang dilakukan dengan melontarkan kata-kata kasar, menyerang, hingga melecehkan korban secara berulang-ulang (Rastati, 2016). Responden mengaku melakukan tindakan ini untuk memojokkan teman ketika berada dalam grup online hingga membuat korban merasa malu.

Ya kayak mem-bully dia, untuk memojokkan dia biar orang lain tertawa gitu.

(Responden A, 12 Maret 2019, UMS) 


\section{(c) Denigration}

Cyberbullying dengan cara memposting pesan hinaan yang tidak benar, gosip, dan rumor mengenai seseorang dengan tujuan memberikan citra buruk (Rastati, 2016). Ketiga responden seringkali bergosip mengenai kelemahan, perilaku, sikap dan kehidupan seharihari orang lain dengan teman mereka. Tindakan ini seringkali dilakukan baik secara personal chat atau dalam grup online.

Gosipin perilaku orang tersebut, sikapnya, kehidupan dia sehari hari yang emang menurut kita tuh agak menyimpang gitu.

(Responden C, 12 Maret 2019, UMS)

\section{(d) Outing}

Cyberbullying yang dilakukan dengan menyebarluaskan sesuatu tentang seseorang yang bersifat memalukan, sensitif, pribadi, dalam bentuk pesan atau gambar (Wangid, 2016). Ketiga responden mengaku sering melakukan tindakan ini dengan cara mem-posting foto/video melakukan teman pada grup online atau fitur story pada aplikasi messenger. Foto/video tersebut bahkan telah di-edit terlebih dahulu agar membuat korban malu.

Biasanya kan ada foto-foto candid, trus ditambahin tulisan tulisan gitu. Trus dikirim ke grup, atau kalau ngga ya story WhatsApp.

(Responden B, 12 Maret 2019, UMS)

\section{(e) Exclusion}

Cyberbullying yang dilakukan dengan mengucilkan seseorang dari grup online secara sengaja. Tindakan ini juga dapat disertai dengan mengeluarkan seseorang dari grup, hingga mengabaikan komentar seseorang di grup online atau social media (Rastati, 2016). Ketiga responden melakukan tindakan ini dengan cara mengeluarkan teman dari grup online karena merasa terganggu atau karena ingin mempermainkannya. Selain itu, ketiga responden juga sering mengabaikan komentar teman di grup online atau social media karena merasa dijatuhkan atau sedang dalam kondisi mood yang tidak baik.

Jadi ya saya keluarkan terus
dimasukkan lagi dikeluarkan
terus dimasukkan lagi.
mempermainkan dia digrup.
(Responden A, 12 Maret 2019 ,
UMS)

\section{Social Media}

Selain aplikasi messenger, media sosial juga menjadi tempat responden dalam melakukan tindakan cyberbullying. Alasan menggunakan media sosial sebagai media untuk melakukan cyberbullying adalah karena korban merupakan orang asing atau karena dengan menggunakan media sosial responden bisa mempermalukan korban dengan lebih leluasa. Tindakan cyberbulling yang dilakukan adalah:

(a) Cyber-stalking

$$
\text { Cyberbullying yang dilakukan }
$$

dengan mengikuti aktivitas social media seseorang hingga membuat orang itu tidak nyaman serta khawatir atas keselamatannya dan mengirimkan pesan berkali-kali yang berisi ancaman, intimidasi (Rastati, 2016). Dalam pengakuannya, responden A mengaku melakukan stalking akun social media orang yang pernah mengolok responden di social media kemudian menghubungi orang tersebut untuk bertemu.

Baru aja kemarin itu ada orang yang mengomentari video saya, bilang kalau video saya itu jelek dan gini gini. Tapi saya liat di akun dia video nya malah lebih jelek. Dan saya cari orangnya, dia ternyata maba. Akhirnya 
Siti Khanifah Putri Kurnia Pratiwi, dkk. Perilaku Cyberbullying mahasiswa dengan...

saya hubungi untuk ketemu langsung, saya kirim pesan "ayo ketemu" gitu. Sampai sekarang belum dibalas, tapi saya akan tetap menghubungi dia sampai bisa bertemu langsung.

(Responden A, 12 Maret 2019, UMS)

\section{(b) Impersonation}

Tindakan meretas akun media sosial seseorang, berpura-pura menjadi seseorang dan membuat akun palsu yang bertujuan membuat seseorang terlihat buruk sehingga reputasi orang tersebut rusak (Rastati, 2016). Responden C mengaku melakukan pembajakan akun social media temannya untuk memposting foto memalukan teman tersebut atau menghubungi seseorang dengan berpurapura menjadi sang pemilik akun. Bahkan responden juga membuat akun social media palsu dengan menggunakan foto saudara sepupu laki-laki nya untuk berkenalan dengan perempuan asing.

Tukeran identitas kayak instagram sama wa kan, wa klonningan gitu. Terus aku pakai nya foto profil adek sepupu aku gitu, yang cowok. Aku kan cuman mau kayak ngerjain dan paling ya pingin ngerti aja anak ini gimana gitu menurutku.

(Responden C, 13 Maret 2019, UMS)

Dengan adanya media online, setiap orang kini dapat menyalurkan pendapatnya dan juga mendapatkan informasi tanpa batasan ruang dan waktu. Hasil penelitian Pramiyanti, dkk (2014) menunjukkan kegaiatan yang berkenaan dengan media online menjadi kegiatan yang paling banyak dilakukan oleh remaja jika dibandingkan dengan kegiatan lain, misalnya mendengarkan radio $(15 \%)$, membaca koran $(10 \%)$, dan membaca majalah (10\%) (Pramiyanti, Putri, \& Nureni, 2014). Selain dapat digunakan untuk membuat citra diri yang baik, media online juga dapat digunakan untuk menjatuhkan citra diri seseorang. Ardianto (dalam Afrilia, 2018) mengatakan bahwa media sosial yang merupakan salah satu bentuk media online sebagai media yang memiliki kekuatan sosial untuk memengaruhi opini publik yang berkembang di masyarakat. Apa yang terdapat dalam media sosial sangat mampu membentuk sebuah opini, sikap, dan perilaku publik/masyarakat. Hal inilah yang dimanfaatkan pelaku cyberbullying dalam menyerang korbannya. Anonimitas juga menjadi salah satu faktor maraknya kasus cyberbullying di media online. Patchin \& Hinduja (Sartana, 2017) menjelaskan bahwa dengan adanya anonimitas, seseorang akan mendapatkan perasaan aman dan terlindungi saat menggunakan media online, memberikan kebebasan kepada individu dari tekanan masyarakat, hati nurani, moralitas, dan etika dalam berperilaku. Hal ini membuat individu kehilangan kontak emosional dengan orang yang berkomunikasi dengan mereka di media online (Sartana, 2017).

\section{SIMPULAN}

Perkembangan teknologi semakin memberikan kemudahan dalam berkomunikasi. Akan tetapi, hal ini juga haruslah diimbangi dengan kesadaran dalam memanfaatkan kemajuan teknologi tersebut dengan bijak. Dalam penelitian ini terlihat bahwa perilaku cyberbullying mahasiswa UMS terdapat pada mahasiswa dengan konsep diri positif dan negatif. Pengalaman menjadi korban bullying juga menjadi salah satu faktor pendorong mahasiswa melakukan tindakan cyberbullying. Hal ini juga berkaitan dengan self esteem mahasiswa dalam kehidupan sehari-hari.

Pola kelekatan (attachment) yang dimiliki oleh mahasiswa dengan orangtua juga memiliki peran terhadap mahasiswa dalam interaksi sehari-hari dengan teman sebayanya. Meskipun tidak ditemukan 
pola kelekatan menghindar (avoidant attachment), akan tetapi banyak tindakan cyberbullying yang dilakukan responden. Mereka cenderung melakukan tindakan cyberbullying kepada teman dekat atau teman sebaya mereka. Tindakan-tindakan cyberbullying tersebut mereka lakukan dengan perantara media online, baik melalui messenger ataupun melalui social media.

Pada penelitian ini peneliti hanya berfokus pada pelaku cyberbullying. Maka, selanjutnya peneliti menyarankan agar penelitian kedepan dapat mengambil sudut pandang korban dan pengamat agar mendapatkan hasil lain yang lengkap dan berbeda. Jika diperlukan, menyertakan hasil wawancara orang tua subjek juga dapat memudahkan peneliti dalam menganalisis pola kelekatan antara orangtua dan anak.

\section{DAFTAR PUSTAKA}

Afrilia, A. M. (2018). Personal Branding Remaja di Era Digital. Mediator: Jurnal Komunikasi, 11(1), 20-30.

Akbar, M. A. (2015). Cyberbullying pada Media Sosial (Studi Analisis Isi tentang Cyberbullying pada Remaja di Facebook). Universitas Sebelas Maret.

Amiruddin. (2016). Metode Penelitian Sosial. Yogyakarta: Parama Ilmu.

APJI. (2017). Penetrasi \& Perilaku Pengguna Internet Indonesia. Apjii (Vol. 2018).

Berthold, K. A., \& Hoover, J. H. (2000). Correlates of Bullying and Victimization among Intermediate Students in the Midwestern USA. School Psychology International, 21 (1).

Cenceng. (2015). Perilaku Kelekatan pada Anak Usia Dini (Perspektif John Bowlby). Lentera, IXX(2), 141-153.

Devito, J. A. (2011). Komunikasi Antarmanusia. Tangerang: Karisma Publishing Group.

Djaelani, A. R. (2014). Teknik Pengumpulan Data dalam Penelitian Kualitatif, $X X$ No 1 .

Drisko, J. W., \& Maschi, T. (2016). Content Analysis. New York: Oxford University
Press.

Kõiv, K. (2012). Attachment Styles Among Bullies, Victims and Uninvolved Adolescents. Psychology Research, 2(3), 160-165.

Makbul, C., \& Agung, I. M. (2016). Self Esteem , Siri ', dan Perilaku Agresif pada Suku Bugis: Sisi Gelap Self Esteem Tinggi. Jurnal Psikologi, 12 Nomor 1.

Malik, I. A. (2018). Hubungan parental support autonomy dengan kecenderungan perilaku cyberbullying remaja. Universitas Islam Negeri Sunan Ampel.

Mawardah, M., \& Adiyanti, M. (2016). Regulasi Emosi dan Kelompok Teman Sebaya Pelaku Cyberbullying. Jurnal Psikologi, 41(1), 60.

Pramiyanti, A., Putri, I. P., \& Nureni, R. (2014). Motif Remaja dalam Menggunakan Media Baru (Studi pada Remaja di Daerah Sub-Urban Kota Bandung). KomuniTi, 6(2), 95-103.

Pujileksono, S. (2015). Metode Penelitian komunikasi Kualitatif. Malang: Intrans Publishing.

Rakhmat, J. (2015). Psikologi Komunikasi. Bandung: PT Remaja Rosdakarya.

Rastati, R. (2016). Bentuk perundungan siber di media sosial dan pencegahannya bagi korban dan pelaku. Jurnal Sosioteknologi, Vol 15 No.

Saifullah, F. (2016). Hubungan Antara Konsep Diri Dengan Bullying pada Siswa-Siswi SMP. Jurnal Psikologi, 4(2), 200-213.

Sartana. (2017). Perundungan Maya (Cyber Bullying ) Pada Remaja Awal. Jurnal Psikologi Insight, 1(1), 25-39.

Satriawan, N., Karyanta, N. A., Studi, P., Fakultas, P., \& Maret, U. S. (2014). Hubungan antara Konsep Diri dengan Toxic Disinhibition Online Effect pada Siswa SMK N 8 Surakarta. Universitas Sebelas Maret.

Setyaningrum, A. (2015). Pengaruh empati, self-control, dan self-esteem terhadap perilaku cyberbullying pada siswa sman 64 jakarta. Universitas Islam Negeri Syarif Hidayatullah.

Vranjes, I., Baillien, E., Vandebosch, H., Erreygers, S., \& De Witte, H. (2017). 
Siti Khanifah Putri Kurnia Pratiwi, dkk. Perilaku Cyberbullying mahasiswa dengan...

The dark side of working online: Towards a definition and an Emotion Reaction model of workplace cyberbullying. Computers in Human Behavior, 69, 324-334.

Wangid, M. N. (2017). Cyberbullying: Student'S Behavior in Virtual Worlds. GUIDENA: Jurnal Ilmu Pendidikan, Psikologi, Bimbingan Dan Konseling, 6(1), 38 .

Watt, R. van der. (2014). Attachment , parenting styles and bullying during pubertal years. Journal of Child \& Adolescent Mental Health, 26(3), 251261.

Wei, H. S. (2011). Friends can hurt you: Examining the coexistence of friendship and bullying among early adolescents. School Psychology International, 32 (3).

Williams, K. (2011). Bullying Behaviors and Attachment Styles. Georgia Southern University. 